Journal of

Applied Crystallography

ISSN 0021-8898

\section{Jerry B. Cohen}

Jerry B. Cohen died on 7 November 1999 at the age of 67. He graduated at MIT, took his $\mathrm{PhD}$ in the Metallurgy Department of MIT in 1957 and spent one year in Professor Guinier's laboratory in Paris with a Fullbright scholarship (1957-1958). He then joined the Materials Science and Engineering Department at the Technological Institute of Northwestern University, where he made his whole career, becoming full Professor in 1965 . He was very active in the life of the University and, during his Chairmanship from 1973 to 1978, the Department of Materials Science and Engineering expanded significantly as a result of his policy. He became Dean of Engineering in 1980 and remained at that post until 1 September 1999. He was awarded many prestigious medals and was many times Chairman of important Committees or Societies. In 1982 he was elected President of the American Crystallographic Association and, from 1976 to 1981 he was Co-editor of the Journal of Applied Crystallography.

A renowned specialist of diffraction methods and of their application to materials science and metallurgy, he made important contributions, inter alia, to the study of order-disorder, particle-size effects, dislocation mechanisms, and the measurement and role of residual stresses in alloys. $\mathrm{He}$ is the author or co-author of over 315 publications and several books.

I met Jerry during our MIT years and he was always a very dependable friend. I

\title{
crystallographers
}

remember with pleasure the happy days I spent visiting him and his wife Lois at their home in Glencoe. He had a sharp mind and an excellent judgement; whenever I needed a referee who did not hesitate to speak his mind for a difficult manuscript, I knew I could call on him. He will be sorely missed by his family and all his colleagues and friends.

\section{André Authier \\ Laboratoire de Minéralogie-Cristallographie \\ Université Pierre et Marie Curie \\ 4 Place Jussieu \\ 75252 Paris CEDEX 05 \\ France}

\section{European Crystallography Prize}

The European Crystallographic Association is to award the first European Crystallography Prize to Professor Ada Yonath of the Weizmann Institute of Science Rehovoth, Israel and the Max-Planck Research Unit for Ribosomal Research, DESY, Hamburg, Germany. Professor Yonath is being recognized for her pioneering achievements in structural studies on the ribosome, the universal cellular organelle on which protein biosynthesis takes place.

The European Crystallography Prize, which includes a monetary award as well as a certificate of recognition, will be presented at the upcoming 19th European Crystallography Meeting to be held in Nancy, France, 25-31 August, at which Professor
Yonath will describe the work for which she is being honored.

Members of the European Crystallography Prize Committee, who were appointed by the Executive Committee of the European Crystallographic Association, are Professor Michael Hursthouse, University of Southampton, UK, Professor Neil Isaacs, University of Glasgow, UK, Professor Jan Kroon, University of Utrecht, The Netherlands, Professor Carlo Mealli, ISSECC-CNR, Florence, Italy, and Professor Eric Mittemeijer, Max Planck Institute for Metals Research and University of Stuttgart, Germany. The Committee was chaired by Professor Joel Bernstein, BenGurion University of the Negev, Beer Sheva, Israel.

Professor Yonath was born in Jerusalem and received her $\mathrm{PhD}$ under the direction of Professor Wolfie Traub at the Weizmann Institute, where she is the incumbent of the Martin A. Kimmel Chair in Structural Biology and Head of the Kimmelman Center for Biomolecular Assemblies. Her pioneering work over many years in pursuit of the ribosome structure, which she has orchestrated on an international scale, has been concentrated in Europe, with a significant portion of her activity centred at the Max-Planck Research Unit in Hamburg, which she also heads.

The European Crystallography Prize is sponsored by Bruker Analytical X-ray, Karlsruhe, Germany, STOE \& CIE GmbH, Darmstadt, Germany and Philips Analytical BV, Almelo, The Netherlands. 